\title{
Iranian-Norwegian Media Consumption
}

\author{
Identity and Positioning
}

\author{
Sharam Alghasi
}

\begin{abstract}
This study examines 20 Iranian-Norwegians and their diverse media consumption. The claim is that the dynamics between media's hegemonic quality, expressed in their discursive representation of realities, and Iranian-Norwegians' subjective positions seem to have a vital impact on the processes of meaning construction and positioning that Iranian-Norwegians experience in Norwegian society. Analysis of the respondents' media preferences indicates that they are most often attracted by three characteristics linked to their status: being Iranian, immigrant and Muslim. These elements emerge as identity markers that IranianNorwegians focus on in their relationship to the media, and furthermore employ in their negotiation of identity and position in Norwegian society. They often express an anomaly between their understanding of themselves, who they are and where they belong, and the discursive representation of them in the media. This results in an attitude of resistance, in the shape of the subjective constructions of the respondents, and which seems to propel them in different directions.
\end{abstract}

Keywords: Iranian Diaspora, multi-consumption, identity, positioning, hegemony, subjectivity

\section{Introduction}

The chief assumption in this study is that the way Iranian-Norwegians experience themselves is related to how they are perceived and understood by others (Berger \& Luckmann 1967, Erikson 1968). Moreover, the media, as an important contemporary meaning-generator, is seen as crucial, having considerable impact upon public understanding and representations of social relationships and identities (Cottle 2000, Kellner 1995). Perceiving and representing social realities, relations and identities is discursive in that a "set of meanings, metaphors and representations together create a particular image of reality and ways of representing this reality" (Burr, 1995:48). Furthermore, the media represents a specific reality, yet the perception of its representation is best understood as occurring within particular structures and states of mind (Kellner 1995, Hall 1997). Accordingly, this study focuses on ways Iranian-Norwegians "within particular structures and states of mind" relate to discursive realities represented in various media. It aims to investigate the impact of this relationship on Iranian-Norwegian processes of identity making. 


\section{Iranian-Norwegians and Discursive Realities of Media}

Previously, according to a certain Marxist interpretation, it was argued that those who own the means of production control the means of producing and thereby the circulation of the ideas of society (Slater 1997). The cultural industry, as defined by Horckheimer and Adorno, expresses a perspective by which individuals possess limited autonomy in their relationship with the media (Adorno 2001). Gradually, this idea of ideological domination, and the limited autonomy of the individual in relation to media, has been subject to major modification due to its shortcomings in dealing with positioning, which can be defined as the ability to perceive media messages differently and to position oneself differently in relation to those messages (Hall 1997). Gramsci's concept of hegemony is a manner of rethinking reality, and its representation, that avoids the model of a fixed reality or fixed sets of codes for representing it. According to Gramsci, hegemony is won in the intervention between competing social, political and ideological forces (Gramsci 1971).

Therefore the question is raised: How do Iranian-Norwegians relate to the discursive realities of media? The assumption of this study is that Iranian-Norwegians possess a potential ability to resist the hegemonic quality of media when reading media texts. This position underlines the polysemy of media texts - the potentially different ways of perceiving social reality. Stuart Hall employs the term decoding, which he defines as the ability of individuals to give media messages new meanings, therefore representing a source of power individuals may have to manipulate media messages (Hall 1973).

However, as Douglas Kellner emphasizes, there is a tendency in cultural studies to celebrate resistance "without distinguishing between types and forms of resistance" (Kellner 1995:11). Obviously, factors such as gender, age group, family, education, class, ethnicity and so forth are important factors in cultural reception (Staiger 1992), not least regarding the Iranian-Norwegian cultural reception of various media texts. Bourdieu emphasizes the various positioning of the individual towards the doxa, the established and often unquestioned definition of reality in the field, according to the individual amount of capital and the habitus that constitute their scheme for perception (Bourdieu 1992).

According to Charles Peirce, a sign is something that represents something else to someone in some respect (Guinard 2002). Subjectivity is marked by the ability to imitate the outer world in an inner world of thought, the use of this ability to subject actions to self-control and, ultimately, the capacity to change through the deliberate formation of new habits (Blunden 2007). Iranian-Norwegians' experience with the media is then assumed to be a reflexive project in which they are steadily gauging and interpreting, nevertheless positioning themselves towards hegemonic representations of the media in their own processes of meaning making and positioning in Norwegian society.

However, the Iranian-Norwegian reflexive project is not simply an individual process, but rather a relational one. According to Stanley Fish, we are all part of different interpretive communities, in the sense that we interpret a text within a cultural context and according to the interpretive community to which we belong, so that we possess a particular way of reading it (Fish 1976). The assumption is that the reflexive project of Iranian-Norwegians involves constructing their own interpretive communities. However, this construction may lead in different directions. It may have a diasporic shape, with them sharing their diasporic experiences with each other and identifying with the same types of experiences. But these experiences are not necessarily limited to other members of the Diaspora. Sharing experiences may also take on a hybrid form in which people, 
independent of ethnic background, may be included in the interpretive community that Iranian-Norwegians continuously construct.

The focus is therefore on what media content respondents prefer to consume, how they interpret this content and its representations within their social context, and how they interact with represented cultural texts in the media they consume (Ang 1996).

\section{Methodological Design}

The study is a qualitative empirical investigation that aims to grasp the subjective constructions of Iranian-Norwegians in their relationship with discursive media representations. ${ }^{1}$ An ethnographic approach is often recognized as the most suitable for this purpose (Lull 1990, Gillespie 2000). Lull describes media ethnography as an enterprise in which the researcher employs observation and in-depth interviewing in order to be able to "enter into the life space of human subjects and get to know them on their own terms" (Lull 1990:3). Gillespie believes that "ethnographic studies contribute to a rich understanding of what people actually do with the media, rather than predictable 'findings' about what the media do to people" (Gillespie 2000:170).

However, the recent ethnographic turn in qualitative audience research has been characterized as a change in focus from decoding to context (Morely 1992). Therefore, the implication that an ethnographic approach is the most suitable for this study as the target is not only to emphasize the process of interpretation, but also to focus on media use as a practice. Ethnographic audience research is a method in which audiences are interviewed and observed in their "natural environment" or context, in order to establish ideas about the media texts the respondents seem to consume in a Norwegian context, as well as to grasp their frame of understanding regarding these texts and contexts (Kvale 1983:184).

The study comprises semi-structural interviews and participant observation with 20 Iranian-Norwegians living in Oslo and its suburbs. Respondents were chosen from a quantitative survey in which 181 Iranian-Norwegians were interviewed. Analysis of the media habits and preferences of Iranian-Norwegians indicates a great degree of complexity within this diasporic group. They consume a wide range of media from different sources; therefore speaking of a "representative" group of Iranian-Norwegian media consumers is a seemingly impossible task. However, in order to construct as representative a sample as possible, a cross-table of Iranian-oriented/Norwegian-oriented TV consumption (Table 1) among the Iranian-Norwegians was constructed (Alghasi, forthcoming):

Table 1. Simplified Cross-table for Iranian and Norwegian Orientations

TV orientation Norwegian orientation

$\begin{array}{clccc} & \text { Values } & \text { Low } & \text { High } & \text { Total } \\ \text { Iranian orientation } & \text { Low } & \text { Group 138 (21\%) } & \text { Group 2 95 (52\%) } & 133 \\ & \text { High } & \text { Group 3 11(6\%) } & \text { Group 4 37 (20\%) } & 48 \\ & \text { Total } & 49(27 \%) & 132(72 \%) & 181(99 \%)\end{array}$


Data for consumption of other media were also provided, and 20 respondents representing different media habits and preferences where chosen for closer study and examination (Table 2):

Table 2. Media Consumption for TV, Newspaper and Radio

\begin{tabular}{lllllllllll} 
Groups & Respondents & \multicolumn{3}{c}{ TV } & \multicolumn{4}{c}{ Newspaper } & \multicolumn{3}{c}{ Radio } \\
& & Iran & Nor. & Int. & Iran & Nor. & Int. & Iran & Nor. & Int. \\
\hline \multirow{2}{*}{ Group 1 } & Behrouz & 0.00 & 0.00 & 0.00 & 0.40 & 1.00 & 0.50 & 0.00 & 0.00 & 0.00 \\
& Arash & 0.00 & 0.14 & 0.29 & 0.80 & 0.80 & 0.75 & 0.00 & 0.11 & 0.38 \\
& Araz & 0.38 & 0.43 & 0.00 & 0.00 & 0.20 & 0.00 & 0.00 & 0.11 & 0.00 \\
& Kaveh & 0.00 & 0.14 & 1.00 & 0.20 & 0.60 & 0.50 & 0.00 & 0.11 & 0.00 \\
& Hassan & 0.13 & 0.29 & 1.00 & 0.60 & 0.40 & 0.75 & 0.44 & 0.00 & 0.88 \\
Group 2 & Afsaneh & 0.00 & 0.71 & 0.71 & 0.60 & 0.80 & 0.75 & 0.22 & 0.67 & 0.63 \\
& Bahman & 0.00 & 0.86 & 0.29 & 0.60 & 1.00 & 0.00 & 0.22 & 0.78 & 0.13 \\
& Bahar & 0.00 & 0.86 & 0.57 & 0.00 & 0.80 & 0.25 & 0.00 & 0.44 & 0.00 \\
& Asghar & 0.00 & 0.86 & 0.86 & 0.40 & 0.80 & 0.50 & 0.00 & 0.22 & 0.13 \\
& Lale & 0.00 & 1.00 & 0.43 & 0.00 & 1.00 & 0.00 & 0.00 & 0.44 & 0.00 \\
& Mohammad & 0.25 & 1.00 & 0.71 & 0.00 & 0.80 & 0.25 & 0.00 & 0.11 & 0.00 \\
& Ali & 0.13 & 0.57 & 0.86 & 0.40 & 0.60 & 0.50 & 0.44 & 0.11 & 0.13 \\
& Elahe & 0.13 & 0.71 & 0.43 & 0.00 & 1.00 & 0.00 & 0.00 & 0.11 & 0.00 \\
Group 3 & Bahram & 0.88 & 0.00 & 0.14 & 0.00 & 0.20 & 0.00 & 0.00 & 0.00 & 0.00 \\
& Morteza & 0.88 & 0.86 & 0.43 & 0.40 & 0.40 & 0.25 & 0.00 & 0.00 & 0.00 \\
& Mozhgan & 0.88 & 0.86 & 0.57 & 0.40 & 0.80 & 0.00 & 0.22 & 0.22 & 0.00 \\
& Said & 0.63 & 0.57 & 0.57 & 1.00 & 0.60 & 0.75 & 0.00 & 0.11 & 0.00 \\
& Yasaman & 1.00 & 0.57 & 0.00 & 0.40 & 0.60 & 0.00 & 0.00 & 0.00 & 0.00 \\
& Pari & 0.75 & 0.57 & 0.57 & 0.00 & 0.80 & 0.00 & 0.00 & 0.11 & 0.00 \\
& Goudarz & 1.00 & 0.57 & 0.00 & 0.60 & 0.80 & 0.00 & 0.00 & 0.00 & 0.00 \\
\hline
\end{tabular}

Note: $1=$ high consumption, $0=$ low consumption.

Table 2 illustrates a major but simple fact: there is a considerable tendency towards multi-consumption despite variations among the respondents. Participant observation and interviewing were employed to further investigate the processes of identity making and positioning that Iranian-Norwegians experience in their relationship with the media.

All respondents were born and raised in Iran. Semi-structured interviews combined with participant observation were employed to investigate a) what sources of media were used and b) the media content that seemed to attract the respondents. Furthermore, the task was set to investigate c) how the respondents read the media messages they consume, and finally d) how the reading of media messages influences the respondents' social relationships.

\section{Identity at Work}

Interviews with the respondent group combined with participant observation indicate that, despite diversity among the respondents in terms of both type of media and type of media orientation, a strikingly common trait can be observed among most of the respondents: there is a significant attraction to issues relating to Iran. This attraction seems to contain three main aspects. 
One aspect is obviously the focus on Iran as one's homeland. The respondents' Iranian background, names, language, appearance and memories make this aspect inevitable in their relationship with the media. To a certain degree, they want information about their homeland. For instance, during the fieldwork and interview phase of the investigation, the Iranian nuclear dispute gained considerable attention in Norwegian and international media. This issue seemed to occupy Iranian conversations to a great extent.

Another aspect is related to the respondents' status as immigrants in Norway. The phenomenon of immigration has become a reoccurring issue in the Norwegian public debate over the past 20 years, which has resulted in a considerable impact on sociocultural and political developments in Norway (Alghasi 1999, Gullestad 2002). Iranians are not just Iranians; they are also immigrants living in Norway.

The third aspect of Iranian-Norwegians' relationship with the media is their focus on Islam. Iran, with a large majority of Muslims in its population, is located in the Middle East and has often received a substantial amount of coverage in Norwegian and international media. Obviously, the events after $9 / 11$ have led to a heightened sensitivity to international media's coverage of not only the Middle East but also of radical Islam as an emerging force impacting global unrest (Eriksen 2001, Eide 2007).

These three elements were particularly evident to the majority of the respondents, who frequently believed these elements to be distinct, vital identity markers that influenced their daily lives and their social relationships within Norwegian society.

\section{Iran, the Homeland}

In spite of their diverse media habits and preferences, the respondents seemed eager to remain up to date on issues linked with their native country. This eagerness is expressed by Kaveh when he is asked about his media habits and preferences:

- I start the day with text TV, usually CNN news. Unfortunately they removed the $\mathrm{BBC}$ from the list of channels we had where I live. (...). sometimes I stay at work 2-3 hours after I've finished and collect international news related to Iran. First, I go to Google and write "Iran" and find different articles on Iran. It is a sort of madness! I also go to Iranian web sites to check up on the news on Iran.

- Do you go to Norwegian sites?

- No. It is mostly international: Reuters, Associated press, Los Angeles Times, New York Times, the Guardian. I look at all of them. My focus is on the issues and events in the Middle East but I also follow other news as well.

- And it is all at work?

- Yes. And sometimes I listen to BBC radio, especially late at night. I focus mainly on international news, but I also follow Norway. I know what is going on here. I am a news junkie! I look at it as a sickness!

- Why?

- Because it really preoccupies lots of my time and focus. I follow lots of analysis on the media.

The quotation above illustrates the need Kaveh has for information on, and his scrutiny of, Iran-related issues, as well as international news specifically related to the Middle 
East. Another respondent, Bahram, points out a similar urge regarding Iran-related issues:

- When I wake up in the morning, I automatically turn on text TV to see what is written. It is very important for me.

- Why is that?

- I like to know. I have lots of feelings for my country. During the American attack on Iraq, when Americans were bombarding the country, I was upset, I was sad, and I was crying. It is like we are unconsciously waiting to see what is going to happen. In a way, I like to know how far things have gone. It has become a habit.

- What would you have done without this TV (Iranian TV)?

- Yeah. I tell my wife: What would we do if we didn't have this TV? It would have been much more difficult.

Bahram's media consumption has a different form to that of Kaveh. While Kaveh consumes a wide range of media from different places, Bahram seems to consume mainly Iranian TV. He empathizes with war victims in Iraq. Pari, another respondent, also emphasizes her attraction to Iran-related issues:

- I like to know how things are, but do not like turning on the TV early in the morning, because I know when I wake up in the morning that my life doesn't allow me to go and turn on the TV. But I know, when I go to work, when I go and read the newspapers and know for instance about the 30-day deadline the US has given Iran. I want to know if something new has been written. On the other hand, I follow Norwegian news. As I said, I don't trust Iranian news. I very seldom go to those channels to learn what they have to say. When we talk to friends, I ask. That is all, but I don't kill myself!

Pari is attracted to Iran-related issues, but compared to Kaveh and Bahram does not seem to be as preoccupied with Iran, and partially explains this by expressing scepticism towards the official Iranian news media. Another respondent, Lale, consumes mainly Norwegian media, but again, expresses heightened attention when Iran is mentioned:

- (...). On the radio it has happened that when they say something about Iran, once I hear the name Iran, it catches my attention.

- What do you do then?

- Then I listen more carefully to hear what the news is, if something has happened, if there is something important.

Iranian-Norwegians have to expend considerable effort in order to remain a jour with media coverage of issues related to Iran. In some cases, as with Kaveh and Bahram, the focus on Iran dominates, while in the cases of and Lale and Pari their attention is somewhat more sporadic. Furthermore, the media sources utilized in their Iran-related media activities are relatively diverse. While Kaveh and Pari are multi-consumers, Bahram's media consumption is limited to Iranian TV, and Lale consumes mostly Norwegian media (see Table 2).

During the fieldwork, two Iran-related issues appeared to draw considerable attention in Iranian-Norwegians: the Iranian nuclear issue and the participation of the Iran national football team in the World Cup in Germany. Respondents consumed various 
media to keep abreast of news items. When focusing on these two news stories, as with any other Iran-related issues, various representations of Iran and Iranianess are continuously under scrutiny and subject to examination. Representations of Iran in the media are often subject to discussion in Iranian-Norwegian gatherings, and appear to raise many emotions among the respondents. One respondent, Morteza, calls a close friend whenever the nuclear issue is a news item in order to report the latest development. He expresses joy when the danger of an attack on Iran is reduced. Another respondent does not check the media about Iran if he expects bad news, but does check it if he feels that things are improving.

\section{Iranian, the Immigrant}

Most Iranians who fled to Norway arrived after 1985 (Statistics Norway 2006). The mid 80 's comprise a significant period of time, marking the emergence of the immigration issue as a major socio-cultural and political phenomenon in Norway (Alghasi 1999, Hagelund 2003, Brochmann 2006). Being an immigrant, along with being Iranian, has therefore been a major dimension of Iranian identification in Norway. This dimension is richly emphasized by the respondents in this study. Bahman names important issues he prefers to follow:

- Issues that have something to do with us, issues that concern Western society; a new law on immigration, for example.

Other respondents also express this attraction to immigration-related issues. As with the search for Iran and Iranianess, the question of being an immigrant generates many opinions and emotions among the respondents. For example, when asked about what media events he was likely to follow Araz answered:

- Items related to immigrant issues and anything related to my work.

- Why are immigrant issues here important to you?

- Because we will never be Norwegian here. We always remain immigrants.

- But what is interesting about these programmes?

- I just want to confirm the plans they are making for immigrants, whether they are positive or negative, but I believe they are more negative. If you don't know about immigrants, how long they have been here and what they do here, they (the media) can attract your attention with the programmes they put on; no matter whether it is positive or negative, I think it leads to racism.

Araz connects his eternal status of being an immigrant to the media and the way his prescribed identity as an immigrant is represented in debate programmes. Television debate programmes have, in recent years, become major forums for debating various immigrant-related issues and have had considerable socio-political impact on Norwegian society. ${ }^{2}$ These issues can vary from the coverage of crime to the question of integration or policy making, such as a new law on immigration (Alghasi 1999). The respondents show a great interest in following these programmes on Norwegian TV. ${ }^{3}$ They take the immigration debate on debate programmes seriously because they consider these issues to have a major impact on their lives in Norway. Another respondent, Hassan, reveals an intense interest in immigration-related issues on Norwegian TV: 
- What do you watch on Norwegian TV?

- Often I watch debate programmes; debate especially between different political parties, about immigrants.

- And what feelings do they produce in you?

- Mainly, I follow debates concerning Norwegian society and the positioning of society towards immigrants, such as me. I am following the political debates between their (Norwegian) political parties. For instance, recently they talked about FrP and how their popularity has increased. I tell myself that they have become so popular because of the immigration issue. ${ }^{4}$

The immigration issue and its representation in Norwegian media are often perceived as crucial, as something that affects the daily life of Iranian-Norwegians. Respondents want to know what is said about "them", and how they are perceived and represented. Along with searching for the media's representation of Iran and Iranianess, the immigration issue is linked to being Iranian: who they are, what identity they feel they have - or what identity they are prescribed by the media.

\section{Iranian, the Muslim}

Along with the Iranian nuclear issue and the football World Cup, the Muhammad caricatures were another intensively debated issue in Norway during the fieldwork. This debate was intense in Norway and unleashed a global reaction when the caricatures were published in a Norwegian magazine on 10 January 2006. This issue was often mentioned during our interviews, and seemed to carry considerable significance for the respondents. Respondents often linked the Muhammad caricatures and the way Islam is portrayed to their identity and to how they are perceived as Iranians. Pari was offended by the Muhammad caricatures, even though she claimed to have no religious beliefs whatsoever. I asked her why she felt insulted. She answered:

- Because I, personally, when they say Iranian, they look at Iranians as Muslim. In many places I don't want to prove what Iranians being Muslim is about (...), but because of my actions and doings they say how strange it is for them that I am not like some others. And I say, no we are not, no. Additionally, I don't like Iran, or being Iranian, questioned all the time. When they say Iran is also a Muslim country, and this happened or that happened, I don't like it. These situations, I feel offended. For example, I didn't get offended by the Muhammad pictures. I didn't feel offended at all. But their perspective about those who are Muslim was changed; on one hand they insisted on saying that Muslims are like that, and on the other hand I insisted on telling them that no, it is not like that, but anyway you have to show some respect. Because I think there is also the opposite, those here in Norway who are very fanatic about Jesus. And if something happens to them I think they will react.

Pari's opinion indicates that respondents feel that a connection is drawn between Iran and Islam. She is identified as not only an Iranian but also a Muslim, as a fixed entity. She challenges these notions by pointing out the diversity that exists. Being related to Islam and the media's focus on Islam seemed to evoke many emotions and opinions in the respondents. I asked Koroush about the impact of the Muhammad caricatures on him: 
- I have seen the caricatures, all of them (...). In my opinion it was not important at all $(\ldots)$ but there is one issue here: respecting religion $(\ldots)$.

- But are you religious?

- No, I am not religious at all, but I respect those who are. They all call me a Muslim even though I say I am not Muslim, but everywhere they look at us as Muslims (...). After 9/11, Muslims and the dark-skinned are more perceived as terrorists than before. And relations are actually very changed.

- How do you know that?

- We feel it.

- How do you feel it?

- Because, myself, when I watch TV I see that Muslims are burning down the embassy, or throwing stones in Iran or Pakistan, as a foreigner living in Norway, I think God, why do they do that? Then I realize that Norwegians are 100 times more negative.

Strikingly, almost all of the respondents emphasized and partly exaggerated their identities as non-Muslim, or not having strong religious beliefs. Furthermore, they associated the caricature issue with a greater public meaning construction by which Islam has been prescribed qualities they want to challenge as well as distance themselves from. Islam, and its implications, is understood as a religion with an immense impact on the daily life of the respondents. The central focus of this investigation is therefore the impact of media representation of issues related to Iran, immigration and Islam on the way the respondents "read" the media's representation of these issues, and therefore their various positioning to related media messages.

\section{Representations and Positioning}

In a semiotic sense, being Iranian, an immigrant and Muslim can be understood as texts related to topics respondents seem to prefer to read. The respondents seem to have a developed an intertextual reading of these texts; that is reading one text in relation to another or others. Furthermore, intertextuality refers to the repertoire of knowledge we already possess, and is fundamental in constructing some meaning before other meanings (Kristeva 1980, Fiske 1987). The interstitial quality in an Iranian reading of media indicates that originating from Iran, being an immigrant and being a Muslim often emerge as a whole and occupy a large space in respondents' relations to the media. This is a space in which Iranian-Norwegians seem to search for confirmation of their identities, but also where they are being placed or are placing themselves in Norwegian social space. Identity and position go hand in hand when respondents analyse their own media consumption. Kaveh was asked why he focuses on Iran so much after living in Norway for more than 22 years. He answers:

- I don't know. I think maybe it is because of this issue of identity (...) there is one main group in the society, and we minorities never feel that we are part of this society (...). The only time they want you to be Norwegian is when they have a football match, then they ask you if you cheered for Norway the other day, and if you say no, they ask, "but aren't you Norwegian?" But otherwise you are Iranian. Three or four times a day, they remind you you're Iranian. 
Kaveh links his media consumption to his sense of belonging to Norwegian society, in which he is identified as non-Norwegian and positioned as such. His mention of sports as a way of identifying with Norway appears to correspond with other related investigations of media representations, in which sports achievers are more easily accepted as Norwegian while those who offend society, such as criminals or deviants, are labelled with words that describe them as foreigners (Lindstad \& Fjeldstad 1997, Eide 2002). Kaveh searches the media, and by his own description predominately international, media to consolidate his identity.

- ...(media) focus on Iran has several features for me. One is that I can't deny the fact that a feeling of nationalism does exist in me. Maybe, I think that if Iran has technological progress maybe it will in a way consolidate my identity here.

Kaveh implicitly questions the representation of himself, his Iranianess and its implications, by the Norwegian media, and looks for other more consolidating elements to take him further in life. Moreover, the majority of respondents link their position in Norwegian society with media representation identifying them in particular positions there. Being unjustly identified and placed seems to concern the respondents. This is a type of continuous assessment that respondents employ when they describe their media consumption. Bahram consumes mainly Iranian TV. In describing his media consumption, he often provides illustrations of Norwegian society and his feeling of being misplaced. When asked why he consumes media in this way, he answers:

- In Norway, they never want to say things in our favour. They always want to show our weaknesses. When they don't want to know about my country, what reason do I have to know about their country? Like the Iranian missile launch. They had ten seconds of news about it, but if Randi's cat is in the trunk of her car, they can talk about it for half an hour. But my country has invented lots of things; they don't show it. They just think of themselves. If they send a journalist to Iran, if you have noticed, they go and collect only negative things. (...) They don't go to see the good things. They don't go to Northern Tehran, they go to Southern Tehran. ${ }^{5}$

- What impact does this have on your sense of belonging here in Norway?

- It really affects me that they represent things wrongly, or do not represent them at all.

Bahram shares Kaveh's oppositional stance regarding the representations of Iran in Norwegian media. They simply do not identify with the media's images of them as Iranian and its various connotations. Other respondents, who consume mainly Norwegian media, may often take the same position towards media representations of Iran, immigrants and Muslims in Norway. A couple, Asghar and Bahar, stopped subscribing to Aftenposten, a major daily newspaper in Norway, reasoning as follows:

- A year ago we had subscriptions to several newspapers in addition to the newspapers we bought daily. But then it had very bad effects on our temper.

- In what way?

- We got very irritated because of all the immigrant-hostile attitudes. Another reason was our children. They have grown up with newspapers and started to read them early. They started with the sports pages, but gradually started reading 
other news. Suddenly, they could read a whole newspaper. We noticed that those they could identify with, colour or background, they were all criminals. That's why we stopped.

Asghar and Bahar have lived in Norway for more than 20 years, speak Norwegian fluently, and express dissatisfaction with the media's representation of them. They characterize this representation as essentialist and as potentially having an impact on their children, in that they cannot find positive role models in their daily newspaper.

To various degrees, respondents often held a critical position towards the representation of the media regarding their Iranianess, immigrant status and Muslim background. Nevertheless, they noticed a link between the media's representation of them and who they are, and the actual position they possess in Norwegian society. During the interviews, respondents refer to immigrant-related issues, the Iranian nuclear issue or the Muhammad caricatures, often associating these issues with their perceived status in Norwegian society. They often express a deep dissatisfaction with the perception and representation of Iran in the media, and consequently with the impact this has on their daily lives in Norway. In some cases, following the media seems to have become an obsession. They develop a type of surveillance activity over Norwegian, and to some extent international, media to confirm what some Iranian-Norwegians believe to be unfair stories about them. One respondent spoke of receiving hostile looks on the bus the day after a debate programme on immigration was aired on Norwegian TV, because he believed that the programme's representation of immigrants was hostile and would create more negative attitudes towards immigrants.

This state of dissatisfaction regarding media representations of Iranians and the social realities around them is not limited to Norwegian media; the respondents often express their opposition to the predominant representations in Iranian media as well. According to Pari, her consumption of Iranian media is mainly concentrated on Iranian music and talk shows broadcast from the US. When asked about her relationship to news and current affairs on Iran-based media, she answers:

- Sometimes when the TV is on, I listen. But I don't follow Iranian news at precise times because I believe there are more accurate versions of what happens in Iran here in Norwegian media. That is why I don't believe much in news from Iranian channels broadcast from Iran. That is why I don't pay attention, because I think they lie.

She illustrates a critical position towards Iranian media. However, this does not stop her from using the Iranian media as a source of entertainment. Respondents often claimed to prefer Norwegian and international media for being less biased than Iranian media. In addition, respondents often criticized the diasporic media. Hassan is very critical of the Norwegian media, but takes the same position towards the Iranian media in exile:

- I have watched Iranian channels from the US. I think some of the programmes are only interesting for the first couple of hours. Apart from that, those channels are very unfair in their analyses. They take sides with a particular group, often pro-Americans. You would expect that those channels would mirror what really happens, but they are broadcast from the US, I am not very satisfied with them.

Hassan often criticizes Norwegian media for being biased, but his criticism also targets Iranian media in exile. He and Bahram - with his Iranian-oriented media consumption - share the same view regarding their critique of Norwegian media. However, as re- 
gards the Iranian media they differ greatly. Bahram believes his life would be much more difficult without Iranian TV at home, while Hassan emerges as a media consumer directed towards international media. Comparing Iranian, Norwegian and international media, he says:

- I think international channels have greater credibility; because if they were partial, for instance, if they took the British or American view, they would surely get a lot of feedback from their viewers. They have understood the necessity of having solid news. But Iranian channels broadcast from the US don't have this credibility and easily produce rubbish.

In some cases, consuming Iranian media, particularly having access to Iranian TV channels at home, is understood as an act of legitimising the regime in Iran. Bahman expresses this position as follows:

- To be honest, I don't like, under any condition, to have something from the regime in my house. Having Iranian TV at home will also mean having some Iranian channels from Iran. Even though there are some advantages of having Iranian channels, I feel that there is a sort of nationalism existing in Iranian TV that I don't want my children to grow up with. My daughter, until lower secondary school, had no picture whatsoever of nationality. She didn't know where she was from. Then at secondary school she started asking questions: "Where I am from?" I didn't want this. I didn't like having a nationalistic or ethnic belonging. And they have been raised that way, I think. I realized that it was not right for the development of my children.

Bahaman's indication reaffirms a major position among the respondents; they often consider themselves as neither Norwegians nor Iranians, and in their arguments often consider the media's representation as vital. They do not seem to identify themselves with the Norwegian representation of them as being Iranian, immigrants and Muslims, and simultaneously are unable to identify with the very idea of Iranianess represented in the Persian-speaking media. The Iranian national media are often perceived as being an extended ideological arm of the Iranian regime, while Iranian diasporic media are mainly considered an insubstantial medium of entertainment or linked to specific groups in political opposition (Alghasi, forthcoming).

\section{Forms of Positioning and Resistance}

Obviously, the focus respondents have on their own portrayal in the media is a structural element in the Iranian-media relationship. Moreover, the impact of media and the way respondents resist the realities media represent seem to be quite diverse and follow definite subjective positions. A closer look at some of the respondents may illustrate how Iranian-Norwegians' attitudes toward the media lead to various forms of meaning constructions, positioning and resistance.

Kaveh can be described as middle-class and has had a political career in the past. At present, in Norway, he is well educated and speaks Norwegian and English fluently. Kaveh's media activity indicates a consumption of a wide range of media in which the Internet plays a vital role. He believes that neither Norwegian nor Iranian media are independent, but visits various websites to search for issues related to Iran. When asked about his feeling of belonging to Norway, he answers: 
- I feel I am a citizen of Oslo, that Oslo is my city. (...). But I feel that society doesn't give me this sense of belonging. I have been dancing Salsa for ten years and I am very good at it. Maybe one or two are better than me. But each time new people talk to me, they ask why I dance Salsa since I am Iranian. Even there I can't escape being Iranian! In these situations you must have some answers like "Why don't you dance traditional Norwegian, since you are Norwegian?"

Kaveh cannot escape a version of Iranianess, which he resists, a version he believes the media is strongly involved in producing and reproducing. Instead, he seems to be involved in a process of identity construction in which dancing Salsa emerges as a natural part after ten years in Europe. Obviously, Kaveh, like other respondents, focuses on how his identity is portrayed in the media and stands as a structural element in the Iranian-media relationship. However, in his case, resisting the media's realities indicates an identity construction with a visible hybrid dimension whereby he constructs his own perception of Iranianess.

Bahram can also be described as middle-class, with an Iranian university education, but his language ability is limited. He expresses his relationship with Iran and Norway as follows:

- Sometimes, my wife and I sit and talk. We feel that everything around us is unnatural. We don't feel that things we have paid for and brought home belong to us. Nothing around us satisfies us. If we want to be satisfied we travel to Iran. My life is limited to the places we have been and the pictures I have taken. I went to Iran; I went to the street where I was born. I stood there and cried. I went to the school I went to. I walked around. I asked where the school was, exactly. I was upset, and I cried.

The position Bahram holds is also illustrated in his media consumption; he is strongly opposed to Norwegian media and his consumption is mostly limited to watching Iranian TV. His life is "the pictures he has taken." His construction indicates an ever-increasing nationalistic feeling for Iran, and his reading of Norwegian media texts about himself, that is his Iranianess, is an oppositional reading whereby he resists media representations. In fact, to him these representations are a reflection of the position in which he believes Norwegian society has placed him.

Kaveh and Bahram indicate an oppositional stand towards Norwegian media, but their construction of meaning and identity seem to take them in different directions. It could be suggested that Kaveh has chosen the direction of constructing something new, while Bahram perceives himself as marginalized and not part of the world he is living in. Another respondent, Pari, shares the same oppositional stand towards Norwegian media representations and the impact of these representations on her daily life. She appears to have her own strategy for facing the media and their representations. When asked about the impact of the media focus on Muslims and immigration on her life, she answers:

- Personally, I don't allow this to influence my daily life. I can't allow myself to be demolished because of such issues. Sometimes, I really get mad that I am here. Then I would like to be in Iran. But I don't sit and get sad about it (the focus on Islam and immigration).

The ways the respondents in this study interact with media indicate dynamic processes of meaning construction and positioning. The respondents find themselves in a media landscape producing social realities that impact their identity and position, a situation 
they often seem to resist. Their interaction with the media may be characterized as a relationship with an impact on Iranian-Norwegian reflexive projects of identity construction - on who they are and where they believe they belong. However, the reflexive projects of the respondents seem to vary greatly. Pari's strategy is to avoid "getting sad"; she has obviously learnt to limit the role of media on her daily life. When asked if she felt Iranian, she answers:

- Yes, very much.

- When?

- When it comes to feelings and emotions, or spending time with family. Of course there are Norwegians who are the same as me. It's not like "Iranian" or "Norwegian"; there are Norwegians feeling the same way as I do. I know a Norwegian lady, we are friends. She speaks better Persian than I do. She has been together with an Iranian guy for 13 years. She loves Iranian food. Some Norwegians are interested in spending more time with family, but not many. Iranians, on the other hand, are more family oriented, they like to get together. But again, there are Iranians who have become very Norwegian I believe, and then they mix up some places, and forget they belong on this side or the other side.

The notion of Iranianess described by Pari is not limited to Iran as a geographical concept, but rather as an extended understanding that allows her to identify herself with Norwegians, while some Iranians, by her measure, are excluded from her understanding of being Iranian.

\section{Construction of Interpreting Communities}

A. Sreberny's study of Iranians living in London indicates the formation of small local groupings based on London districts of residence, and "some pre-existing but newly elaborated ethnic, linguistic or political-cultural line of differences. Simply put, there are many real and potential Iranian communities in London, not just a single one" (Sreberny 2000:186). The media consumption of the respondents in this study indicates a process of constructing their own interpretive communities, as Stanley Fish (1976) defines the term. They construct their own interpretive communities, depending on the form of their rejection of the discursive ideas of their Iranianess in either or both the Norwegian and Iranian media. In these communities, they are able to identify their own subjective position with those with whom they share a close relationship.

Most of the respondents in this study reject the dominant ideas of their Iranianess as represented in Norwegian and Iranian media. One way this construction can be illustrated is through their sharing of their diasporic experiences with other Iranian-Norwegians who may recognize and identify with these experiences. However, these experiences are not necessarily limited to other members of the Diaspora. Often, the social relationships of this group includes people of diverse ethnic backgrounds who appear to share the same values and attitudes, not least regarding the media's discursive realities about immigrants.

\section{Conclusions}

Iranian-Norwegian relationships with the media indicate the existence of a reflexive project amongst them. This project may be understood as a subjective attempt at recog- 
nition, searching for others' definitions and opinions concerning their Iranianess, who they are and where they belong, simultaneously defining and redefining who they believe they really are, and where they believe they really belong.

This study's respondents' relationships with the media may be characterized as a steady effort to define and redefine their identity and position in Norwegian society. This concerns the society they live in, as well as the one they have left behind. This claim is supported by the respondents' considerable focus on issues linked to markers of their status; that is their being Iranian, their being immigrants, and their Muslim background. These issues stand as identity markers among the respondents, and are accordingly important for Iranian-Norwegians' processes of meaning making and positioning. They often resist the media's discursive representation of these issues. However, the respondents' subjective constructions seem to have a vital impact on the way they resist. Nevertheless, the forms this resistance takes, which are forms of meaning construction, identity making and positioning, differ and take them in different directions.

\section{Notes}

1. The study also employs quantitative data from another PhD article (For more see Alghasi, forthcoming).

2. Norwegian television debate programmes with the issue of immigration on their agenda attract nearly half a million viewers, which is a high rating for any TV programme in Norway (Norwegian media barometer).

3. For more on this issue, see Alghasi 2007.

4. FrP, or the Progress Party, is a right-wing political party in Norway known for, among other things, their anti-immigration stance. During the interviews for this study, according to various polls FrP commanded nearly $30 \%$ of votes nationwide, and was the second largest political party in Norway.

5. Tehran, like other cities, is divided into distinctive areas, north and south. The northern part is historically known for being wealthy, while the southern part is associated with the opposite.

\section{Literature}

Adorno, T.W. (2001) The Cultural Industry: Selected Essays on Mass Culture. Routledge Publishing.

Alghasi, S. (1999) Slik er de, slik er vi og slik er verden. A Sociological Study of Immigration Represented in NRK and TV2. University of Oslo: The Institute of Sociology and Social Geography.

Ang, I. (1996) Living Room Wars: Rethinking Media Audiences for a Post-modern World. Routledge Publishing.

Berger, P.L. \& Luckmann, T. (1967) The Social Construction of Reality: A Treatise in the Sociology of Knowledge. Penguin Group.

Bourdieu, P. \& Wacquant L., J.D. (1995) Den kritiske ettertanken. Oslo: Det Norske samlaget.

Bourdieu, P. (1989) Distinction: A Social Critique of the Judgement of Taste. London: Routledge.

Blunden, A. (2007) The Subject. Draft in progress.

Brochmann, G. (2006) Hva er innvandring. Universitetsforlaget.

Eide, E. (2002)"Down There" "Up Here" "Europe's Others" in Norwegian Feature Stories. University of Oslo: University publishing.

Eide, E. (2007) 'Critique, Anger and Understanding', in Kunelius, Eide et.al. (eds): Reading the Mohammed Cartoons Controversy. Freiburg: Projekt Verlag.

Eriksen, T.H. (2001) Bak fiendebilde, Oslo: Cappelen forlag.

Erikson, E.H. (1968) Identity: Youth and Crisis. New York: Norton.

Fish, S. (1976) 'Interpreting the Variorum', Critical Inquiry Journal, University of Chicago.

Fiske, J. (1987) Television Culture. London: Methuen.

Gillespie, M. (2000) 'Transnational Communications and Diaspora Communities', in Simon Cottle (ed.) Ethnic Minorities and Media. Buckingham: Open University Press.

Gramsci, A. (1971) [1929-1935] Selections from Prison Notebooks. New York: International Publishers.

Guinard, P. (2002) Critical Analysis of Peirce's Semiotics (and an Ontological Justification of the Concept of the Impressional). 
Gullestad, M. (2002) Det norske sett med nye øyne: Kritisk analyse av norsk innvandringsdebatt. Oslo: Universitetsforlaget.

Hagen I. \& Wasko J. (1999) Consuming Audiences? Production and Reception in Media Research. New Jersey: Hampton Press, inc. Cresskill.

Hagelund, A. (2003) The Importance of Being Decent. Political Discourse on Immigration in Norway 19702002. Oslo: Unipax.

Hall, S. (ed.) (1997) Cultural Representations and Signifying Practices. Sage Publications.

Jensen, K.B. \& Jankowski N.W. (1991) 'Five Traditions in Search of the Audience', European Journal of Communication, vol. 5, 1990, pp. 207-238.

Kellner, D. (1995) 'Cultural Studies, Multiculturalism and Media Culture', in Gail Dines, \& Jean M. Humez (ed.) Gender, Race, and Class in Media. Thousand Oaks, Calif.: Sage, pp. 5-17.

Kristeva, J. (1980) Desire in Language : A Semiotic Approach to Literature and Art (ed. by L.S. Roudiez; transl. by T. Gora, A. Jardine and L.S. Roudiez) New York: Columbia University Press.

Lindstad, M. \& Fjeldstad, Ø. (1997) Innvandrere, fremmedfrykt og norske medier: en undersøkelse av utvalgte mediers dekning av saker knyttet til innvandrere og flyktninger, fremmedfrykt og rasisme. Oslo: Journalisthøyskolen.

Lull, J. (1990) Inside Family Viewing: Ethnographic Research on Television's Audiences. London and New York: Comedia.

Morely, D. (1992) Television, Audiences and Cultural Studies. New York: Routledge.

Slater, D. (1997) Consumer, Culture and Modernity. Polity Press in Association with Blackwell Publishing Ltd.

Sreberny, A. (2000) 'Media and Diasporic Consciousness: An Exploration among Iranians in London', in Cottle, Simon (ed.) Ethnic Minorities and Media. Buckingham: Open University Press.

Staiger, J. (1992) Interpreting Films: Studies in the Historical Reception of American Cinema. Princeton, NJ: Princeton University Press.

Statistic Norway / SSB (2006) Immigration and Immigrants 2006. Series: Statistical Analyses (SA 87).

SHARAM ALGHASI, Cand.polit., Ph.d. fellow, Faculty of Social Sciences, University of

Oslo, sharam.alghasi@culcom.uio.no 